\title{
Effect of Formic Acid Used in Pickle on the Recycling of Spent Chrome Liquor
}

\author{
Kazuhiko Itoh, Shigeo NaKagawa \\ and Takahide OKayama
}

Faculty of Agriculture, Kobe University, Kobe-shi 657

(Received September 16, 1982)

\begin{abstract}
The effect of formic acid added in pickle in the tanning using the recycled spent chrome liquor was determined. Formic acid added in pickle was transfered to the chrome liquor through the pickled skin, and accumulated in the recycled spent chrome liquor to mask the chromium complex during nine runs of tanning gradually. By cation exchange chromatography and paper electrophoresis, it was shown that the electric charge of these chromium compounds in the recycling of spent chrome liquor tended to nonionic charge from cationic one. However, the masking with formic acid did not make a highly masked complex that would cause trouble for leather-making with recycled spent chrome liquor. Moreover, there was no significant effect on the quality of resultant leather in this system.

Ipn. J. Zootech. Sci., 54 (4): 263-268, 1983
\end{abstract}

In the last ten years, several studies have been reported on the recycling of spent chrome liquor in order to reduce the pollution from a tannary effluent and save the chrome as a resource.

Davis and ScRoGgre ${ }^{1-4}$ ) have used the spent chrome liquor within the pickling/ tanning one bath process in recycling of spent chrome liquor, and Niwa et al..$^{5}$ ) have used in the tanning process after drain of pickle solution. And they recognized that the recycling of spent chrome liquor did not affect the composition of chrome tanning liquor and the quality of finished leather essentially. WADA et al.6) have made it clear by cation exchange chromatography, paper electrophoresis, and gel filtration, that recycling of the spent chrome liquor in the twenty runs of tanning does not essentially affect its chrome complex composition. KuBo et al. ${ }^{7}$ ) have obtained a similar result on the composition of chrome complex in recycled spent chrome liquors by cation exchange chromatography within a tanning of pigskin.

In the recycling of spent chrome liquor, the formic acid added in a pickle solution for promoting the penetration of pickle acid into the skin is gradually transfered in the chrome liquor together with pickled skin. Excess of formic acid accumulated in the chrome liquor and coordinated to the chromium complexes during twenty runs recycling of spent chrome liquor and was suspected to weaken the binding of chromium complexes to collagen.

The authors have investigated the effect of formic acid added in pickle solution on the composition of spent chrome liquor which includes the amount of formic acid 
and a charge distribution of chrome complexes, which is considered to be affected with formic acid during the recycling of spent chrome liquor in the twenty runs of tanning.

\section{Materials and Methods}

Chrome tanning and recycling of spent chrome liquor

Wet-salted kip skins (12 kg/piece) from Holland were soaked, limed, delimed and bated by standard procedures as follows:

wash: with 500 percent water for 5.5 hours.

soak: with 500 percent water for 16 hours.

lime: with 500 percent water $\left(25^{\circ} \mathrm{C}\right), 4$ percent calcium hydroxide, 2 percent sodium sulfide, and 1 percent sodium hydrosulfide for 48 hours and split. Then relime with 500 percent water and 10 percent calcium hydroxide for 16 hours.

delime: with 500 percent water $\left(35^{\circ} \mathrm{C}\right), 0.1$ percent hydrochloric acid, 0.4 percent and ammonium chloride and 0.5 percent bating agent (Oropon $\mathrm{N}$ from Rohm bate \& Haas corp.), $\mathrm{pH} 8 \sim 9$.

(percentages based on the limed weight)

Chrome tanning was carried out in a separate bath after pickle solution was drained. And the spent chrome liquor was recovered and used as the base for tanning liquor. Experiments of chrome tanning and recycling of spent chrome liquor were continued to twenty runs. Detailed procedures are as follows:

\section{Pickle}

40 pieces of delimed side pelts (limed pelt weight $192 \mathrm{~kg}$ ) were treated in a test drum $\left(150 \mathrm{~cm}\right.$ in diameter and $90 \mathrm{~cm}$ in width) with 80 percent water $\left(25^{\circ} \mathrm{C}\right)$ and 8 percent sodium chloride, the drum was run for 5 minutes, 0.5 percent formic acid ( 85 percent) and 1.0 percent sulfuric acid (Bé $66^{\circ}$ ) diluted with 10 percent water were added and the drum was run for 2 hours followed by horse up overnight, $\mathrm{pH}$ was 2.8.

\section{Chrome tanning}

$4.5 \mathrm{~kg}$ (equivalent to the limed weight of $6.8 \mathrm{~kg}$ ) of pickled side pelts were treated in a test drum $(50 \mathrm{~cm}$ in diameter and $33 \mathrm{~cm}$ in width, at a speed of $20 \mathrm{rpm}$ ) with 30 percent water and 3 percent sodium chloride. After the drum was run for $5 \mathrm{~min}$ utes, 8 percent sulfite-reduced chrome agent (chromosal B from Bayer corp.) was added and the drum was run for 30 minutes followed by addition of 1.1 percent sodium bicarbonate to achieve a basicity of 48 percent. Then the drum was run for 1 hour at $30^{\circ} \mathrm{C}$, and 60 percent water $\left(30^{\circ} \mathrm{C}\right)$ was added. The drum was run again for 2 hours at $30^{\circ} \mathrm{C}, 2$ hours at $35^{\circ} \mathrm{C}$, and 1 hour at $40^{\circ} \mathrm{C}$.

The second and subsequent runs of chrome tanning in the twenty runs of this system were performed by the bath of 10 percent water and 80 percent spent chrome liquor from the preceding tanning bath which was adjusted to $\mathrm{pH} 2.8$ and to contain the same chrome concentration as that in the first run. 


\section{Analyses of spent chrome liquor}

Spent chrome liquors were subjected to the following analyses after filtration through a 60-mesh screen and filter paper of analytical grade. Chrome content and basicity were determined by official method of the ALCA. Sodium and chloride ions contents were measured using ion-selective electrodes. Sulfate ion content was determined by benzidine method, and coordinate sulfate content was calculated from the difference between sulfate ion and total sulfate content which was determined gravimetrically after boiling the chrome liquor in 10 percent acetic acid solution for 1 hour.

Formic acid added in the pickle solution is expected to be transfered to the chrome tanning liquor through the pickled skin. In recycling of spent chrome liquor, the formic acid accumulates in the chrome liquor to coordinate in the chromium complexes. Formic acid in the spent chrome liquor was steam distilled and titrated with $0.1 \mathrm{~N}$ sodium hydroxide.

Analyses of chromium complexes

The electric charge of the cationic chromium complexes in the spent chrome liquor recycled decreases by the coordinated formic acid. Charge distribution of chromium compounds was determined by cation exchange chromatography and paper electrophoresis. Chrome complexes in spent chrome liquor were separated into four fractions on the column of Dowex 50W-Xl cation exchange resin, Na-form, 100-mesh. Fraction 1 had no affinity to the resin, which was classified as anionic and nonionic chromium complexes, fraction 2 eluted with $0.1 \mathrm{~N}$ hydrochloric acid from the column was classified as $[\mathrm{Cr}]^{+}$complex, and fraction 3 eluted with $3 \mathrm{~N}$ hydrochloric acid was classified as $[\mathrm{Cr}]^{3+}$ complex. Fraction 4 eluted with $6 \mathrm{~N}$ hydrochloric acid was classified as highly olated complex ${ }^{8}$. The relative amount of each fraction was calculated on the basis of chrome content.

Paper electrophoresis of chromium complexes was done with Whatmann No. 1 filter paper and electrolytes (potassium nitrate and nitric acid) at the $\mathrm{pH}$ value of chrome liquor, for 2.5 hours at $400 \mathrm{~V}$. Chromium complexes on the filter paper were developed by oxidation with sodium hydroxide and hydrogen peroxide and determined by densitometry".

\section{Mechanical properties of leather}

Effect of formic acid added to the pickle solution was examined for the meshanical properties of resultant leather tanned with chrome liquor recycled during twenty runs of tanning. Examinations were carried out by using specimen $20 \times 20 \mathrm{~cm}$ collected from butt portion of leather dried with acetone. Tensile and tongue tear strength and elongation at break were measured according to JIS K 6550 . Grain crack was measured according to JIS $\mathrm{K} 6548$.

\section{Results and Discussion}

The general composition of spent chrome liquor recycled was shown in Table 1. Sodium and sulfate ions and coordinate sulfate increased a little until the fourth run 
IToh, Nakagawa and OKayama

Table 1. Composition of spent chrome liquor in recycling

\begin{tabular}{cccccccc}
\hline Run No. chrome ratio & $\begin{array}{c}\text { Residual } \\
\%\end{array}$ & $\begin{array}{c}\text { Basicity } \\
\text { ch }\end{array}$ & $\mathrm{pH}$ & $\begin{array}{c}\mathrm{Na}^{+} \\
\mathrm{mol} / l\end{array}$ & $\begin{array}{c}\mathrm{Cl}^{-} \\
\mathrm{mol} / l\end{array}$ & $\begin{array}{c}\mathrm{SO}_{4}= \\
\mathrm{mol} / l\end{array}$ & $\begin{array}{c}\mathrm{SO}_{4}^{*} \\
\mathrm{~mol} / l\end{array}$ \\
\hline 1 & 43 & 38 & 3.23 & 1.02 & 0.533 & 0.205 & 0.061 \\
2 & 40 & 30 & 3.23 & 1.07 & 0.550 & 0.229 & 0.058 \\
3 & 42 & 29 & 3.35 & 1.07 & 0.533 & 0.265 & 0.077 \\
4 & 41 & 27 & 3.36 & 1.10 & 0.540 & 0.283 & 0.089 \\
5 & 43 & 27 & 3.28 & 1.14 & 0.540 & 0.290 & 0.092 \\
7 & 47 & 29 & 3.20 & 1.12 & 0.544 & 0.285 & 0.118 \\
10 & 46 & 29 & 3.20 & 1.16 & 0.567 & 0.294 & 0.098 \\
15 & 45 & 30 & 3.23 & 1.09 & 0.537 & 0.290 & 0.089 \\
20 & 39 & 27 & 3.30 & 1.05 & 0.548 & 0.277 & 0.077 \\
\hline
\end{tabular}

*Coordinate sulfate content.

of tanning and the amounts of these components were stable in the subsequent runs. These results were in accord with those obtained by DAvis and SCROGGIE ${ }^{1)}$ and WADA et $a l^{6}{ }^{6}$.

The content of formic acid in the spent chrome liquor recycled was shown in Fig. 1, and the electric charge distribution of chromium compounds determined by cation exchange chromatography and paper electrophoresis were shown in Figs. 2 and 3 respectively. The formic acid content in the spent chrome liquor increased stepwise during the initial nine runs of tanning, and it decreased a little in the subsequent runs. Also the electric charge distribution showed a drastic change during the initial nine runs of tanning.

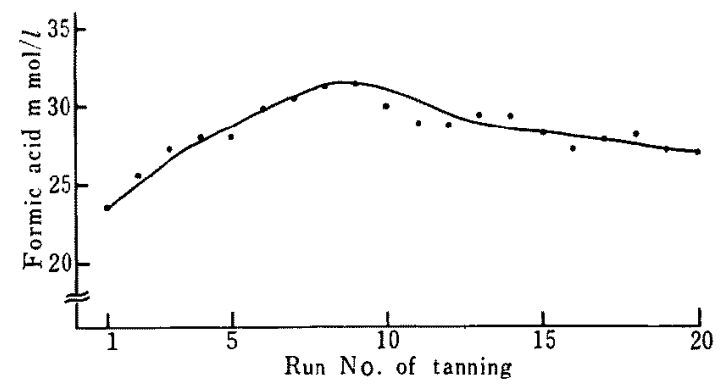

Fig. 1. Content of formic acid in the spent chrome liquor recycled.

As the runs proceeded, the amounts of $[\mathrm{Cr}]^{-}$and $[\mathrm{Cr}]^{0}$ complexes increased, while that of $[\mathrm{Cr}]^{3+}$ complex decreased and after the nineth run an equilibrium was attained (Fig. 2). The amounts of complexes of $[\mathrm{Cr}]^{+}$and highly olated complex were a little and showed a little change in initial nine runs. Moreover, in Fig. 3, it was recognized that uncharged chromium compounds increased and cationic chromium compounds decreased in the spent chrome liquor recyled during ten runs of tanning, comparatively. 


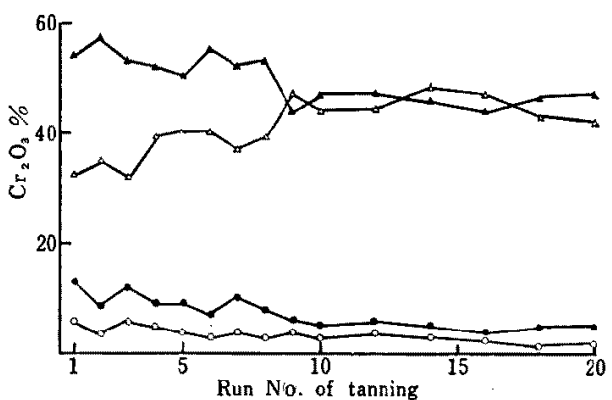

$\triangle:(\mathrm{Cr})^{-}$and $[\mathrm{Cr})^{0} \mathrm{O}:(\mathrm{Cr})^{+} \Delta:(\mathrm{Cr}]^{3+}$

Fig. 2. Charge distribution of chromium compounds in the recycled spent chrome liquor by cation exchange chromatography.

Fig. 3. Paper electrophoregrams of spent chrome liquors recycled. Conditions: Whatmann No. $1, \mathrm{KNO}_{3}-\mathrm{HNO}_{3}(\mu 0.1), \mathrm{pH} 2.8,400 \mathrm{~V}$, $2.5 \mathrm{hr}$, developed with $\mathrm{NaOH} / \mathrm{H}_{2} \mathrm{O}_{2}$.

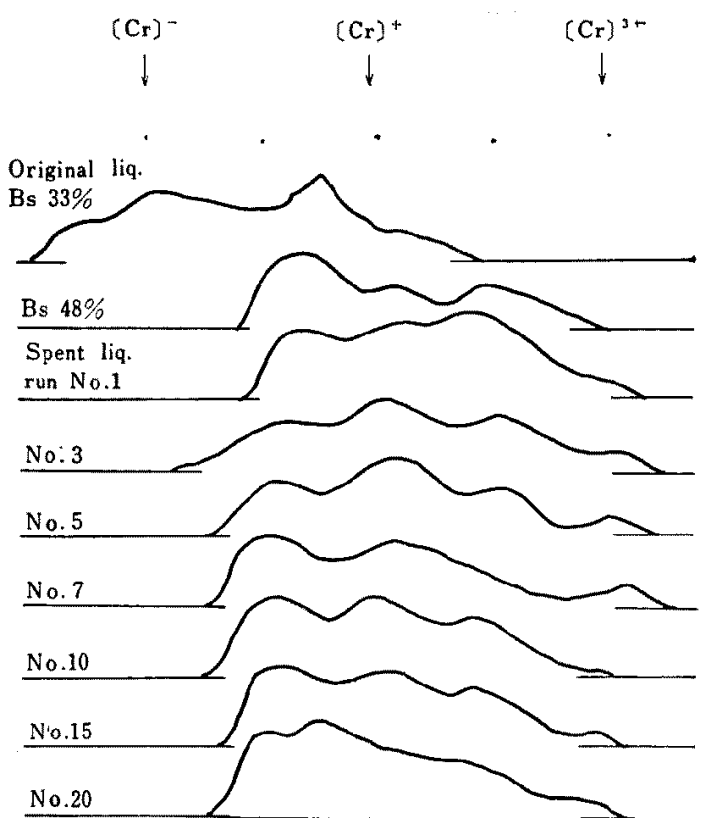

By the study on the formic acid content and the electric charge distribution in the spent chrome liquor recycled, it was clarified that the chromium compounds in the spent chrome liquor was masked with formic acid added in the pickle solution. It was reported that the masking effect of formic acid on the chromium complexes was very weak comparing with other organic acids, and formic acid did not coordinate to a chromium complex readily ${ }^{10}$. Fig. 1 showed that formic acid accumulated gradually in the spent chrome liquor recycled. During nine runs of tanning, this formic acid was coordinated to the chromium complex as shown in Figs. 2 and 3.

In addition, it was found that the masking of the chromium complex with formic acid did not form a highly masked complex, which would cause trouble in leathermaking in the recycling of spent chrome liquor, during twenty runs of tanning.

The mechanical properties of resultant leather tanned with the recycled chrome liquors were shown in Table 2. No significant effect on the quality of resultant

Table 2. Mechanical properties of resultant leather

\begin{tabular}{|c|c|c|c|c|c|}
\hline \multirow{2}{*}{ Run No. } & \multicolumn{2}{|c|}{ Strength } & \multirow{2}{*}{$\begin{array}{c}\text { Elongation } \\
\text { at break } \\
(\%)\end{array}$} & \multicolumn{2}{|c|}{ Grain crack test } \\
\hline & $\begin{array}{c}\text { tensile } \\
\left(\mathrm{kg} / \mathrm{mm}^{2}\right)\end{array}$ & $\begin{array}{l}\text { tongue tear } \\
(\mathrm{kg} / \mathrm{mm})\end{array}$ & & $\begin{array}{l}\text { load at } \\
\text { grain crack }\end{array}$ & $\begin{array}{c}\text { load at } \\
7 \mathrm{~mm} \text { height }\end{array}$ \\
\hline 1 & 1.6 & 2.0 & 159 & 59 & 18 \\
\hline 3 & 1.9 & 2.3 & 141 & 84 & 29 \\
\hline 5 & 1.7 & 2.9 & 155 & 35 & 26 \\
\hline 7 & 1.6 & 2.5 & 158 & 75 & 27 \\
\hline 10 & 1.6 & 2.8 & 132 & 58 & 34 \\
\hline 15 & 2.2 & 3.2 & 145 & 58 & 47 \\
\hline 20 & 1.7 & 3.3 & 158 & 76 & 26 \\
\hline
\end{tabular}




\title{
ITOH, NAKAGAWA and OKayama
}

leather by recycling of spent chrome liquor during twenty runs of tanning was found.

\section{References}

1) Davis, M. H. and J. G. Scroggie, J. Soc. Leather Tech. Chem., 57: 53-58. 1973.

2) Davis, M. H. and J. G. Scrocgte, J. Soc. Leather Tech. Chem., 57: 81-83. 1973.

3) Dayis, M. H. and J. G. Scroggie, J. Soc. Leather Tech. Chem., 57: 173-176. 1973.

4) Davis, M. H. and J.G. Scroggie, Das Leder, 31: 1-8. 1980.

5) Niwa, Y., M. Kawakami and I. Yokokawa, Hikaku-Kagaku, 21: 232-243. 1975.

6) WadA, K., K. Shiral and T. Kubo, J. Am. Leather Chem. Ass., 76: 333-342. 1981.

7) Kubo, T. and Y. Ishil, Jpn. J. Zootech. Sci., 52: 308-313. 1981.

8) Kawamura, A. and K. Wada, J. Am. Leather Chem. Ass., 52: 476-488. 1957.

9) Kawamura, A. and K. Wada, J. Am. Leather Chem. Ass., 62: 612-635. 1967.

10) van Vlimmeren, P. J., J. Am. Leather Chem. Ass., 57: 52-63. 1962.

\section{クロムなめし排水の循環利用における 浸酸に用いたギ酸の影響}

\author{
伊藤和彦・中川成男・岡山高季 \\ 神戸大学農学部, 神戸市 657
}

ピックル液に添加したギ酸がクロムなめし排水定循環 利用する過程で，ク口ム液の組成と革質に与党る影響を 検討した。ナトリウム，硫酸イオンなどクロム液の組 成は偱環の 3〜5回までは变動したが，その後は安定し た。

ピックル液に添加したギ酸は浸酸皮によってクロム液 中に移行し，9回までの循環の間にクロム夜中に蓄積し， その間に徐々にクロム錯塩に配位して，錯塩はカチオン
からフニオンに多少移行する㑯向が見られる.これはイ オン交換クロマトグラフィー及び汇紙電気泳動法による 荷電分布の分析で明らかとなった。し加し20回の排水の 循環利用で，クロム錯塩は過度のアニオン化むなく，革 の機械的強度を測定した結果からも，革質に異常がない こと苏認められた。

日畜会報, $54(4) ： 263-268,1983$ 